\title{
Article \\ The Effect of the Foliar Application of Biostimulants and Fertilisers on the Growth and Physiological Parameters of Maiden Apple Trees Cultivated with Limited Mineral Fertilisation
}

\author{
Sławomir Świerczyński * (1), Agnieszka Antonowicz and Joanna Bykowska \\ Department of Ornamental Plants, Dendrology and Pomology, Poznań University of Life Sciences, \\ Dąbrowskiego 159, 60-594 Poznań, Poland; agnieszka.studiom2@gmail.com (A.A.); \\ joanna.bykowska@up.poznan.pl (J.B.) \\ * Correspondence: slawomir.swierczynski@up.poznan.pl; Tel.: +48-61848-7955
}

Citation: Świerczyński, S.;

Antonowicz, A.; Bykowska, J. The Effect of the Foliar Application of Biostimulants and Fertilisers on the Growth and Physiological Parameters of Maiden Apple Trees Cultivated with Limited Mineral Fertilisation. Agronomy 2021, 11, 1216. https:// doi.org/10.3390/agronomy11061216

Received: 22 April 2021

Accepted: 10 June 2021

Published: 15 June 2021

Publisher's Note: MDPI stays neutral with regard to jurisdictional claims in published maps and institutional affiliations.

Copyright: (c) 2021 by the authors. Licensee MDPI, Basel, Switzerland. This article is an open access article distributed under the terms and conditions of the Creative Commons Attribution (CC BY) license (https:/ / creativecommons.org/licenses/by/ $4.0 /)$.

\begin{abstract}
The article describes an experiment conducted on maiden apple trees of selected cultivars growing in a nursery. The aim of the study was to investigate how the foliar application of four biostimulants (Aminoplant 0.4\%, Biamino Plant 0.2\%, Bispeed 0.2\% and Fylloton 0.4\%) and two fertilisers (Basfoliar 6-12-6 and Basfoliar 12-4-6+S both at a concentration of 0.5\%) affected the growth of the trees cultivated with the mineral fertilisation reduced by half. The plants were sprayed with the preparations and fertilisers four times at three-week intervals, between late May and late July. Selected parameters of the plants' physiological processes were also assessed: net photosynthetic rate $(\mathrm{Pn})$, transpiration rate $(\mathrm{E})$, stomatal conductance $(\mathrm{C})$ and intracellular $\mathrm{CO}_{2}$ (I). The foliar application of all the biostimulants and fertilisers significantly improved the growth of the maiden apple trees. The lowest values of the plant growth parameters were noted in the control combination, which was treated with a full dose of mineral fertiliser. The foliar spraying of the apple trees particularly improved the total length and number of side shoots and the fresh weight of maiden apple trees. The apple tree cultivars differed in their growth parameters, and the influence of individual foliar treatments was not conclusive. The foliar application of selected preparations intensified the leaf transpiration coefficient and the internal concentration of carbon dioxide, but it did not increase the net photosynthesis intensity or stomatal conductance.
\end{abstract}

Keywords: nursery; net photosynthetic rate; transpiration rate; stomatal conductance; intracellular $\mathrm{CO}_{2}$

\section{Introduction}

Poland is the largest producer of maiden apple trees in Europe and the third largest apple producer in the world. Large amounts of mineral fertilisers are used in nursery production to intensify the vegetative growth of fruit trees. On the other hand, plants do not use large amounts of nutrients supplied with mineral fertilisers, because these are leached into deeper soil layers, where they degrade the environment [1-5]. Plants can absorb more nutrients at a faster rate if foliar fertilisation is applied, especially at low temperatures [6,7]. According to some authors $[1,8,9]$, the combination of these two methods of plant nutrition guarantees the best results in the cultivation of apple trees. Bi and Scagel [10] recommended the foliar fertilisation of trees in nurseries. Bearing in mind the recommendation to reduce soil fertilisation, foliar fertilisation effectively meets the nutritional requirements of plants [6]. Biostimulants are also used in sustainable horticulture as environmentally friendly products [11-13], which help to reduce the consumption of mineral fertilisers $[14,15]$. Plant biostimulants contain some nutrients (marine plant extracts, humic acids, amino acids and other natural products such as saponins and compost teas) that stimulate plant growth, even when administered in small amounts [16]. However, research has shown that the concentration of auxins in most biostimulants is too low to effectively stimulate the growth of the plant root system [17]. It is the development of the 
root system that influences the absorption of nutrients. However, in sustainable horticulture, fertilisation is less intensive and nutrients are supplied at low concentrations [18]. Biostimulants not only intensify the growth of roots, but also increase the absorption of nutrients [19]. It is believed that the amino acids and peptides contained in biostimulants may act as signalling molecules in a similar manner to hormones [20].

Experiments have confirmed the positive effects of the Aminoplant ${ }^{\mathrm{TM}}$ amino acid preparation [21,22]. Some authors [23,24] believe that Aminoplant mainly affects the physicochemical parameters (nitrate content, rutoside and kaemperol-3-o-glucoside content in leaves) of plants and has a lower influence on their growth and yield. Earlier studies have shown that such biostimulants increased the yield, because they stimulated the uptake of nitrogen from the soil, especially during droughts [21,25]. Maini [21] used a similar biostimulant on the laboratory studies and observed that it increased the yield of maize seeds, even when the dose of nitrogen fertiliser was reduced by half. The Atonik ${ }^{\mathrm{TM}}$ biostimulant (based on three synthetic nitrophenols, with a similar composition to Bispeed ${ }^{\mathrm{TM}}$ ) improved the growth of plants $[26,27]$. The experiments also showed that protein hydrolysates as a biostimulant improved the photosynthetic activity, which resulted in a higher yield [28]. Biostimulants containing marine algae and seaweeds stimulated the growth of various plant species, e.g., apples [29,30], grapevines [31], pears [32] and strawberries [33]. Zang et al. [34] found that seaweed extract applied to leaves stimulated the activity of enzymes assimilating nitrogen. Kocira et al. [35] observed that the Fylloton ${ }^{\mathrm{TM}}$ preparation (brown algae extract) increased the intensity of photosynthesis in leaves. Many studies showed that the marine algal extract increased the content of chlorophyll in leaves $[19,21,31,36,37]$. The spraying of maize plants with fulvic acid improved their growth as a result of the increased net photosynthetic rate, transpiration rate and the intercellular concentration of $\mathrm{CO}_{2}$ [38]. Some other studies [39-41] showed that biostimulants (amino acid and animalderived) applied to various plant species improved their physiological parameters, e.g., the photosynthetic rate, stomatal conductance and transpiration rate, while increasing their carbon assimilation efficiency.

Macroelements, as well as microelements such as B, $\mathrm{Zn}, \mathrm{Mn}$ and Fe, are regularly applied to counteract their deficiency, especially in fruit trees [42]. It has been proven that fruit plants, both rootstocks [43] and apple trees [44], easily absorb microelements applied to their leaves, which positively affects their growth. Świerczyński et al. [45] and Świerczyński and Stachowiak [46] studied the influence of foliar fertilisation (urea, lime and magnesium saltpetre) on the growth of maiden apple trees in a nursery, but they did not observe a significant improvement in the growth of the plants after these treatments. Biostimulants (humic and fulvic acids or amino acids) intensified the development of the aerial part of almond rootstock, especially in the first year of cultivation in a nursery [47]. The application of biostimulants to year-old almond trees gave similar results [48]. The foliar application of the Humisol biostimulant (humic acids $15 \%, \mathrm{~N} 0.5 \%$ and $\mathrm{K}_{2} \mathrm{O} 2 \%$ ) and other elements $(\mathrm{Ca}, \mathrm{S}, \mathrm{Mg}, \mathrm{Zn}, \mathrm{Fe}, \mathrm{Cu}, \mathrm{B}$ and $\mathrm{Mn})$ improved the growth of nut trees in a nursery [49]. Popenoe et al. [50] did not observe any significant improvement in the growth of ornamental plants in a nursery after the application of biostimulants. Differences in the growth of the plants which were treated or not treated with the biostimulants depended on the species.

The aim of the experiment was to find whether the application of foliar biostimulants and fertilisers could reduce the dose of mineral soil fertilisation by half without an adverse effect on the growth of maiden apple trees in the nursery. The research was carried out on the most important fruit tree species in Poland in terms of production and using the biostimulants and fertilisers most commonly found in the market.

\section{Materials and Methods}

\subsection{Plant Material and Growth Conditions}

The experiment was conducted on maiden apple trees of four cultivars: 'Gala Schniga', 'Ligol', 'Red Boskoop' and 'Topaz', grown on the M.9 rootstock. Between 2016 and 2018, 
three series of experiments were conducted in a strip system in a nursery. One series of experiments consisted of two years of cultivation in a nursery. In the first year, apple varieties on the M.9 rootstock were budded. In the second year, during the growth of maiden trees, foliar spraying was applied. Before each new series of experiments, phosphorus-potassium fertilisation was applied in early spring (2015, 2016 and 2017), and nitrogen fertilisation in three divided doses was applied during the growth of the plants in the nursery (2015-2016, 2016-2017 and 2017-2018). A full dose of mineral fertilisation was applied in the first strip, and the dose was reduced by half in the second strip (Table 1).

Table 1. Treatments used in the experiment.

\begin{tabular}{|c|c|c|}
\hline & Doses of Fertilisation & Container of Biostimulants and Fertilisers \\
\hline Control & $\begin{array}{l}\mathrm{N} 120 \mathrm{~kg} \cdot \mathrm{ha}^{-1} \\
\mathrm{P}_{2} \mathrm{O}_{5} 40 \mathrm{~kg} \cdot \mathrm{ha}^{-1} \\
\mathrm{~K}_{2} \mathrm{O} 140 \mathrm{~kg} \cdot \mathrm{ha}^{-1}\end{array}$ & \\
\hline Aminoplant $0.4 \%$ & $\begin{array}{l}\mathrm{N} 60 \mathrm{~kg} \cdot \mathrm{ha}^{-1} \\
\mathrm{P}_{2} \mathrm{O}_{5} 20 \mathrm{~kg} \cdot \mathrm{ha}^{-1} \\
\mathrm{~K}_{2} \mathrm{O} 70 \mathrm{~kg} \cdot \mathrm{ha}^{-1}\end{array}$ & $\begin{array}{l}18 \mathrm{~L} \text {-amino acids and bioactive peptides ( } \mathrm{N} 8.5 \% \text {; organic } \\
\text { substance } 54 \% \text { : bioactive peptides } 82.7 \% \text {, amino acids } 17.3 \% \text { ) }\end{array}$ \\
\hline Biamino Plant $0.2 \%$ & $\begin{array}{l}\mathrm{N} 60 \mathrm{~kg} \cdot \mathrm{ha}^{-1} \\
\mathrm{P}_{2} \mathrm{O}_{5} 20 \mathrm{~kg} \cdot \mathrm{ha}^{-1} \\
\mathrm{~K}_{2} \mathrm{O} 70 \mathrm{~kg} \cdot \mathrm{ha}^{-1}\end{array}$ & $\begin{array}{l}\text { L-amino acids of plant origin (organic nitrogen } 7.6 \% \text {, organic } \\
\text { carbon } 21.0 \% \text {, amino acids } 42.6 \%, \mathrm{Fe} 1.2 \% \text {, Mn } 0.6 \% \text {, Zn } 0.7 \% \text { ) }\end{array}$ \\
\hline BiSpeed $0.2 \%$ & $\begin{array}{l}\mathrm{N} 60 \mathrm{~kg} \cdot \mathrm{ha}^{-1} \\
\mathrm{P}_{2} \mathrm{O}_{5} 20 \mathrm{~kg} \cdot \mathrm{ha}^{-1} \\
\mathrm{~K}_{2} \mathrm{O} 70 \mathrm{~kg} \cdot \mathrm{ha}^{-1}\end{array}$ & $\begin{array}{c}\text { potassium 4-nitrophenolate } 0.25-0.30 \% \mathrm{~m} / \mathrm{m} \text {, potassium } \\
\text { 2-nitrophenolate } 0.14-0.20 \% \mathrm{~m} / \mathrm{m} \text {, potassium } \\
\text { 5-nitroguaiacolate } 0.07-0.10 \% \mathrm{~m} / \mathrm{m}\end{array}$ \\
\hline Fylloton $0.4 \%$ & $\begin{array}{l}\mathrm{N} 60 \mathrm{~kg} \cdot \mathrm{ha}^{-1} \\
\mathrm{P}_{2} \mathrm{O}_{5} 20 \mathrm{~kg} \cdot \mathrm{ha}^{-1} \\
\mathrm{~K}_{2} \mathrm{O} 70 \mathrm{~kg} \cdot \mathrm{ha}^{-1}\end{array}$ & $\begin{array}{l}\text { brown algal extract (Ascophyllum nodosum) and plant-derived } \\
\text { amino acids (organic nitrogen } 6 \% \text {, organic carbon } 20.8 \% \text {, } \\
\text { organic substance } 35 \% \text { ) }\end{array}$ \\
\hline Basfoliar 2.0 6-12-6 0.5\% & $\begin{array}{l}\mathrm{N} 60 \mathrm{~kg} \cdot \mathrm{ha}^{-1} \\
\mathrm{P}_{2} \mathrm{O}_{5} 20 \mathrm{~kg} \cdot \mathrm{ha}^{-1} \\
\mathrm{~K}_{2} \mathrm{O} 70 \mathrm{~kg} \cdot \mathrm{ha}^{-1}\end{array}$ & $\begin{array}{c}\mathrm{N} 6 \%, \mathrm{P}_{2} \mathrm{O}_{5} 12 \%, \mathrm{~K}_{2} \mathrm{O} 6 \% \text {, B } 0.01 \% \text {, Cu } 0.01 \% \text {, Fe } 0.02 \% \text {, Mn } 0.01 \\
\% \text {, Mo } 0.005 \% \text {, Zn } 0.05 \%\end{array}$ \\
\hline Basfoliar $2.012-4-6+S$ 0.5\% & $\begin{array}{l}\mathrm{N} 60 \mathrm{~kg} \cdot \mathrm{ha}^{-1} \\
\mathrm{P}_{2} \mathrm{O}_{5} 20 \mathrm{~kg} \cdot \mathrm{ha}^{-1} \\
\mathrm{~K}_{2} \mathrm{O} 70 \mathrm{~kg} \cdot \mathrm{ha}^{-1}\end{array}$ & $\begin{array}{c}\mathrm{N} 12 \%, \mathrm{P}_{2} \mathrm{O}_{5} 4 \%, \mathrm{~K}_{2} \mathrm{O} 6 \% \text {, sulphur and } \mathrm{B} 0.01 \%, \mathrm{Cu} 0.01 \%, \mathrm{Fe} \\
0.02 \% \text {, Mn } 0.01 \% \text {, Mo } 0.005 \% \text {, Zn } 0.05 \%\end{array}$ \\
\hline
\end{tabular}

Before the nursery was established, the soil had been analysed chemically. It contained

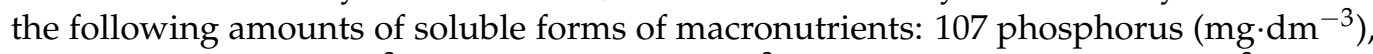
145 potassium $\left(\mathrm{mg} \cdot \mathrm{dm}^{-3}\right), 520$ calcium $\left(\mathrm{mg} \cdot \mathrm{dm}^{-3}\right)$ and 96 magnesium $\left(\mathrm{mg} \cdot \mathrm{dm}^{-3}\right)(\mathrm{mean}$ value for 2015-2017). The total rainfall in individual years of the study was: $500 \mathrm{~mm}(2016)$, $338 \mathrm{~mm}$ (2017) and $228 \mathrm{~mm}$ (2018).

\subsection{Biostimulants and Fertiliser Experiment}

In the second year of the nursery production, which was the first year of growth of maiden apple trees growth, seven combinations were randomly distributed in the strips of maiden trees of each cultivar. Following that, six of them were subjected to foliar treatment with biostimulants and fertilisers with half doses of mineral fertilisers, and one of them was the control combination with full doses of mineral fertilisers with distilled water spraying. Each of the 28 experimental combinations (6 with foliar spraying and one control, 4 apple varieties) was represented in one plot by 10 maiden apple trees, in triplicate. The trees were treated with four preparations at concentrations recommended by the manufacturers (Aminoplant 0.4\%, Biamino Plant 0.2\%, Bispeed 0.2\% and Fylloton 0.4\%) and two foliar fertilisers: Basfoliar 6-12-6 and Basfoliar 12-4-6+S, both at a concentration of $0.5 \%$. The plants were sprayed with the preparations and fertilisers by added Slippa adjuvant $(0.7 \%)$ four times at three-week intervals, between late May and late July. In each plot where 10 trees were used, $0.5 \mathrm{~L}$ of the prepared biostimulant or fertiliser solution was used during spraying. 


\subsection{Plant Measurements and Experimental Design}

All maiden trees in the plot were measured and observed in triplicate for each combination. The following parameters of the maiden trees were measured: height-from the ground surface of soil to the top $(\mathrm{cm})$, trunk diameter $-20 \mathrm{~cm}$ above the budding site $(\mathrm{mm})$, the length and number of side shoots. The side shoots longer than $5 \mathrm{~cm}$ were taken into account. After being removed from the nursery, the maiden trees without soil were weighed to determine their fresh weight $(\mathrm{g})$.

In 2017, on the maiden apple trees growing in the field, directly before, during and immediately after the last foliar spraying, the following parameters were measured with a CI-340 Handheld Photosynthesis device (CID BIOSCIENCE Inc., Camas, WA, USA): net photosynthetic rate $(\mathrm{Pn})\left(\mu \mathrm{molCO}_{2} \cdot \mathrm{m}^{-2} \cdot \mathrm{s}^{-1}\right)$, transpiration rate $(\mathrm{E})\left(\mu \mathrm{mol} \mathrm{H}_{2} \mathrm{O} \cdot \mathrm{m}^{-2} \cdot \mathrm{s}^{-1}\right)$, stomatal conductance (C) $\left(\mathrm{mol} \mathrm{H}_{2} \mathrm{O} \cdot \mathrm{m}^{-2} \cdot \mathrm{s}^{-1}\right)$, intracellular $\mathrm{CO}_{2}$ (I) $\left(\mathrm{mol} \mathrm{CO}_{2} \cdot \mathrm{mol}^{-1}\right)$. The research was conducted at a constant intensity of photosynthetically active radiation (PAR) $\left(1000 \mu \mathrm{mol} \cdot \mathrm{m}^{-2} \cdot \mathrm{s}^{-1}\right)$ supplied to the plants and at a constant concentration of carbon dioxide $\left(\mathrm{CO}_{2}\right)\left(390 \mu \mathrm{mol} \mathrm{CO} \mathrm{mol}^{-1}\right.$ of air). One leaf from the middle part of the long shoot was randomly selected for the measurements, which were made in four replications, four maiden apple trees for each combination.

\subsection{Data Analysis}

The results of the study were analysed with the STATISTICA 13.1 (Statsoft Polska, Kraków, Poland). Pearson's linear correlation coefficient between the studied growth features and the separately assessed physiological parameters was calculated, and its statistical significance was verified. Next, homogeneous groups for individual traits and treatments were calculated with Tukey's HSD test. Multivariate analyses of variance (MANOVA) based on Wilk's test were conducted. The statistical significance level was $p=0.05$.

The growth parameters of the maiden trees were subjected to three-way analyses of variance. The experimental factors were: the apple tree cultivars, years of the experiment and foliar spray combinations. The results of measurements of the physiological parameters were analysed separately by means of two-way analyses of variance, where the apple tree cultivars and foliar treatments were the factors.

\section{Results}

\subsection{Biometric Parameters}

The measurements of the mean heights of the four apple tree cultivars showed that the shortest maiden trees were found in the control combination, whereas the trees in all the other combinations sprayed with the foliar preparations were significantly taller (Table 2). Over all the treatments, the cultivars 'Gala Schniga' and 'Red Boskoop' were the tallest and cultivar 'Topaz' was the shortest (Table 2).

The maiden trees of all the cultivars in the control combination were characterised by the smallest trunk diameter. The value of this parameter was significantly higher in all the other combinations subjected to the foliar treatments (Table 2). Over all treatments, cultivar 'Red Boskoop' had the largest trunk diameter and cultivar 'Ligol' had the smallest (Table 2).

The mean total length of the side shoots of the maiden trees of all the cultivars was significantly lower in the control combination. All foliar treatments yielded greater total lengths of the side shoots (Table 2). The trees of the 'Gala Schniga' cultivar had the largest total length of the side shoots. The smallest total length of side shoots was noted in the 'Topaz' and 'Red Boskoop' cultivars (Table 2).

The maiden trees of all the cultivars in the control combination were characterised by the smallest mean number of side shoots. All of the four biostimulants applied to the trees resulted in a greater number of side shoots (Table 2). The smallest number of side shoots was observed in the maiden trees of the 'Red Boskoop' cultivar; the largest number-in the 'Gala Schniga' cultivar (Table 2). 
The maiden trees treated with the Aminoplant, Biamino Plant and Bispeed biostimulants were characterised by the largest fresh weight. The lowest fresh weight was noted in the control plants (Table 2). The fresh weight of the 'Red Boskoop' trees was significantly lower than the fresh weight of the trees of the other cultivars (Table 2).

Table 2. Growth parameters of four cultivars of maiden apple trees subjected to four biostimulants and two fertiliser treatments (mean from years 2016-2018).

\begin{tabular}{|c|c|c|c|c|c|c|c|c|c|}
\hline & & Control & $\begin{array}{c}\text { Amino- } \\
\text { Plant }\end{array}$ & $\begin{array}{l}\text { Biamino } \\
\text { Plant }\end{array}$ & Bispeed & Fylloton & $\begin{array}{c}\text { Basfoliar } \\
\text { 6-12-6 }\end{array}$ & $\begin{array}{l}\text { Basfoliar } \\
12-4-6+S\end{array}$ & $\begin{array}{l}\text { Mean for } \\
\text { Cultivar }\end{array}$ \\
\hline \multirow{5}{*}{ Height (cm) } & Gala Schniga & $136.0 \mathrm{hi}$ & $152.6 \mathrm{~lm}$ & $146.6 j-m$ & $149.5 \mathrm{k}-\mathrm{m}$ & $149.4 \mathrm{k}-\mathrm{m}$ & $147.9 \mathrm{k}-\mathrm{m}$ & $144.4 \mathrm{i}-1$ & $146.6 \mathrm{c}$ \\
\hline & Ligol & $106.3 \mathrm{a}$ & $118.6 c-f$ & $122.9 \mathrm{e}-\mathrm{g}$ & $125.8 \mathrm{fg}$ & $130.8 \mathrm{gh}$ & $116.3 \mathrm{~b}-\mathrm{e}$ & $123.2 \mathrm{e}-\mathrm{g}$ & $120.6 \mathrm{~b}$ \\
\hline & R. Boskoop & $138.6 \mathrm{~h}-\mathrm{j}$ & $149.0 \mathrm{k}-\mathrm{m}$ & $147.5 \mathrm{k}-\mathrm{m}$ & $143.1 \mathrm{i}-\mathrm{k}$ & $138.4 \mathrm{~h}-\mathrm{j}$ & $150.7 \mathrm{k}-\mathrm{m}$ & $154.8 \mathrm{~m}^{\circ}$ & $146.0 \mathrm{c}$ \\
\hline & Topaz & $107.9 \mathrm{ab}$ & $121.7 \mathrm{c}-\mathrm{f}$ & $124.8 \mathrm{fg}$ & $122.5 \mathrm{~d}-\mathrm{f}$ & $117.5 \mathrm{c}-\mathrm{f}$ & $113.7 \mathrm{a}-\mathrm{c}$ & $114.4 \mathrm{a}-\mathrm{d}$ & $117.5 \mathrm{a}$ \\
\hline & $\begin{array}{l}\text { Mean for } \\
\text { treatment }\end{array}$ & $122.2 \mathrm{a}$ & $135.5 \mathrm{c}$ & $135.5 \mathrm{bc}$ & $135.3 \mathrm{bc}$ & $134.0 \mathrm{bc}$ & $132.1 \mathrm{~b}$ & $134.2 \mathrm{bc}$ & \\
\hline \multirow{5}{*}{$\begin{array}{l}\text { Diameter } \\
(\mathrm{mm})\end{array}$} & Gala Schniga & $11.4 \mathrm{a}-\mathrm{c}$ & $12.6 \mathrm{f}-1$ & $12.4 \mathrm{~d}-\mathrm{k}$ & $12.9 \mathrm{j}-1$ & $12.2 \mathrm{c}-\mathrm{k}$ & $12.4 \mathrm{~d}-1$ & $12.1 \mathrm{~b}-\mathrm{j}$ & $12.3 \mathrm{~b}$ \\
\hline & Ligol & $10.7 \mathrm{a}$ & $11.1 \mathrm{ab}$ & $11.8 \mathrm{~b}-\mathrm{h}$ & $11.2 \mathrm{a}-\mathrm{c}$ & $12.6 \mathrm{f}-1$ & $11.5 \mathrm{a}-\mathrm{d}$ & $11.7 \mathrm{~b}-\mathrm{f}$ & $11.5 \mathrm{a}$ \\
\hline & R. Boskoop & $11.9 \mathrm{~b}-\mathrm{i}$ & $12.8 \mathrm{i}-1$ & $12.8 \mathrm{~h}-1$ & $12.7 \mathrm{~g}-1$ & $12.2 \mathrm{c}-\mathrm{k}$ & 13.31 & $12.8 \mathrm{i}-1$ & $12.6 \mathrm{c}$ \\
\hline & Topaz & $11.6 \mathrm{a}-\mathrm{e}$ & $12.5 \mathrm{e}-1$ & $12.5 \mathrm{e}-1$ & $13.1 \mathrm{k}-1$ & $12.5 \mathrm{e}-1$ & $12.6 \mathrm{e}-1$ & $11.8 \mathrm{~b}-\mathrm{g}$ & $12.4 \mathrm{~b}$ \\
\hline & $\begin{array}{l}\text { Mean for } \\
\text { treatments }\end{array}$ & $11.4 \mathrm{a}$ & $12.3 \mathrm{bc}$ & $12.4 \mathrm{bc}$ & $12.5 \mathrm{c}$ & $12.4 \mathrm{bc}$ & $12.5 \mathrm{bc}$ & $12.1 \mathrm{~b}$ & \\
\hline \multirow{5}{*}{$\begin{array}{c}\text { Sum of } \\
\text { long shoots }\end{array}$} & Gala Schniga & $75.6 \mathrm{f}-\mathrm{i}$ & $156.3 n$ & $133.5 \mathrm{mn}$ & $159.4 \mathrm{n}$ & $124.5 \mathrm{~lm}$ & $114.9 \mathrm{k}-\mathrm{m}$ & $108.9 \mathrm{j}-\mathrm{m}$ & $124.7 \mathrm{c}$ \\
\hline & Ligol & $36.7 \mathrm{a}-\mathrm{d}$ & $51.4 \mathrm{~b}-\mathrm{f}$ & $82.7 \mathrm{~g}-\mathrm{j}$ & $57.5 \mathrm{c}-\mathrm{g}$ & $97.3 \mathrm{i}-1$ & $39.9 \mathrm{a}-\mathrm{d}$ & $90.8 \mathrm{~h}-\mathrm{k}$ & $65.2 \mathrm{~b}$ \\
\hline & R. Boskoop & $33.4 \mathrm{a}-\mathrm{d}$ & $30.0 \mathrm{a}-\mathrm{c}$ & $27.4 \mathrm{ab}$ & $42.3 \mathrm{a}-\mathrm{e}$ & $40.9 \mathrm{a}-\mathrm{d}$ & $39.8 \mathrm{a}-\mathrm{d}$ & $53.0 \mathrm{~b}-\mathrm{g}$ & $38.1 \mathrm{a}$ \\
\hline & Topaz & 19.7 a & $40.7 \mathrm{a}-\mathrm{d}$ & $72.1 \mathrm{e}-\mathrm{i}$ & $62.1 \mathrm{~d}-\mathrm{h}$ & $45.8 \mathrm{a}-\mathrm{f}$ & $38.7 \mathrm{a}-\mathrm{d}$ & $41.7 \mathrm{a}-\mathrm{d}$ & $45.9 \mathrm{a}$ \\
\hline & $\begin{array}{l}\text { Mean for } \\
\text { treatment }\end{array}$ & $41.4 \mathrm{a}$ & $69.6 \mathrm{bc}$ & $78.9 \mathrm{c}$ & $80.3 \mathrm{c}$ & $77.1 \mathrm{c}$ & $58.2 \mathrm{~b}$ & $73.6 \mathrm{c}$ & \\
\hline \multirow{5}{*}{$\begin{array}{l}\text { Number of } \\
\text { lateral } \\
\text { shoots }\end{array}$} & Gala Schniga & $3.6 \mathrm{i}-\mathrm{k}$ & $5.7 \mathrm{~m}$ & $4.9 \mathrm{~lm}$ & $5.2 \mathrm{~lm}$ & $5.1 \mathrm{~lm}$ & $4.3 \mathrm{kl}$ & $3.8 \mathrm{jk}$ & $4.7 \mathrm{c}$ \\
\hline & Ligol & $1.2 \mathrm{ab}$ & $2.3 c-f$ & $3.3 \mathrm{~g}-\mathrm{j}$ & $2.4 \mathrm{~d}-\mathrm{g}$ & $3.4 \mathrm{~h}-\mathrm{k}$ & $1.6 \mathrm{a}-\mathrm{e}$ & $2.6 \mathrm{e}-\mathrm{h}$ & $2.4 \mathrm{~b}$ \\
\hline & R. Boskoop & $1.1 \mathrm{ab}$ & $0.7 \mathrm{a}$ & $0.9 \mathrm{a}$ & $1.2 \mathrm{ab}$ & $1.4 \mathrm{a}-\mathrm{d}$ & $1.3 \mathrm{a}-\mathrm{c}$ & $1.4 \mathrm{a}-\mathrm{d}$ & $1.2 \mathrm{a}$ \\
\hline & Topaz & $1.2 \mathrm{ab}$ & $2.7 \mathrm{f}-\mathrm{i}$ & $2.6 \mathrm{e}-\mathrm{h}$ & $2.5 \mathrm{e}-\mathrm{h}$ & $2.5 \mathrm{e}-\mathrm{h}$ & $2.1 \mathrm{~b}-\mathrm{f}$ & $2.3 \mathrm{~d}-\mathrm{g}$ & $2.3 \mathrm{~b}$ \\
\hline & $\begin{array}{l}\text { Mean for } \\
\text { treatment }\end{array}$ & $1.8 \mathrm{a}$ & $2.7 \mathrm{~cd}$ & $2.9 \mathrm{~cd}$ & $2.8 \mathrm{~cd}$ & $3.1 \mathrm{~d}$ & $2.3 \mathrm{~b}$ & $2.5 \mathrm{bc}$ & \\
\hline \multirow{5}{*}{$\begin{array}{l}\text { Fresh weight } \\
\text { of plants (g) }\end{array}$} & Gala Schniga & $401.1 \mathrm{~b}-\mathrm{e}$ & $550.0 \mathrm{mn}$ & $517.2 \mathrm{k}-\mathrm{n}$ & $505.6 \mathrm{i}-\mathrm{n}$ & $476.1 \mathrm{f}-\mathrm{k}$ & $476.7 \mathrm{~g}-\mathrm{k}$ & $472.2 \mathrm{f}-\mathrm{k}$ & $485.6 \mathrm{~b}$ \\
\hline & Ligol & $388.9 \mathrm{~b}-\mathrm{d}$ & $451.1 \mathrm{e}-\mathrm{j}$ & $538.91-n$ & $524.4 \mathrm{k}-\mathrm{n}$ & $494.4 \mathrm{~h}-\mathrm{m}$ & $486.7^{\mathrm{g}-1}$ & $504.4 \mathrm{~h}-\mathrm{m}$ & $484.1 \mathrm{~b}$ \\
\hline & R. Boskoop & $321.7 \mathrm{a}$ & $448.9 \mathrm{~d}-\mathrm{i}$ & $402.2 \mathrm{~b}-\mathrm{e}$ & $426.7 \mathrm{c}-\mathrm{g}$ & $353.9 \mathrm{ab}$ & $429.4 \mathrm{c}-\mathrm{g}$ & $416.1 \mathrm{c}-\mathrm{f}$ & 399.8 a \\
\hline & Topaz & $375.0 \mathrm{a}-\mathrm{c}$ & $510.0 \mathrm{j}-\mathrm{n}$ & $542.81-\mathrm{n}$ & $565.6 \mathrm{n}$ & $482.8 \mathrm{~g}-1$ & $473.9 \mathrm{f}-\mathrm{k}$ & $444.4 \mathrm{~d}-\mathrm{h}$ & $484.9 \mathrm{~b}$ \\
\hline & $\begin{array}{l}\text { Mean for } \\
\text { treatment }\end{array}$ & $371.7 \mathrm{a}$ & $490.0 \mathrm{~cd}$ & $500.3 \mathrm{~d}$ & $505.6 \mathrm{~d}$ & $451.8 \mathrm{~b}$ & $466.7 \mathrm{bc}$ & $459.3 \mathrm{~b}$ & \\
\hline
\end{tabular}

Data followed by the same letters do not differ significantly at $p=0.05$ for each parameter according to Tukey's test. The influence of the years was not statistically significant.

There were significant correlations between all the growth parameters of the maiden apple trees. The only exception was the nonsignificant relationship between the height of the maiden trees and their fresh weight (Table 3).

Table 3. The correlations between the studied parameters of growth (averages for the three years 2016-2018).

\begin{tabular}{cccccc}
\hline Parameters & Height & Diameter & Slss & Number of Shoots & Weight of Plants \\
\hline Height & 1.00 & & & & \\
Diameter & $0.44^{*}$ & 1.00 & & & \\
Slss & $0.34^{*}$ & $0.42^{*}$ & 1.00 & & \\
Number of shoots & $0.27^{*}$ & $0.33^{*}$ & $0.94^{*}$ & 1.00 & 1.00 \\
Weight of plants & 0.07 & $0.31^{*}$ & $0.48^{*}$ & $0.50 *$ & \\
\hline
\end{tabular}

The level of significance $p=0.05$, Pearson's linear correlation coefficient. Slss-Sum of lengths of side shoots * Significant relationship between parameters.

To sum up the results of all growth parameters, the lowest values were noted in the control combination (Table 2).

\subsection{Physiological Parameters}

The highest significant value of the net photosynthetic rate (Pn) in all the cultivars was noted after the treatment with the Basfoliar 6-12-6 fertiliser (Table 4). The smallest net photosynthetic rate was observed after the treatment with the Fylloton biostimulant, 
followed by Bispeed - these values were lower than in the control plants. The Pn value of the 'Red Boskoop' cultivar was significantly lower than those in the other cultivars (Table 4).

The treatment of the maiden trees with all the preparations resulted in a significantly higher transpiration rate than in the control plants (Table 4). The highest transpiration rate was observed after the treatments with Basfoliar 6-12-6 and Basfoliar 12-4-6+S. The 'Topaz' maiden trees were characterised by the highest transpiration rate (E) of all the cultivars (Table 4).

The lowest stomatal conductance $(\mathrm{C})$ was noted in the maiden trees treated with the Bispeed biostimulant; the highest-after the treatment with Basfoliar 6-12-6 and Fylloton (Table 4). These results did not differ from the control combination. The value of this parameter in the 'Topaz' trees was significantly higher than those in the other cultivars (Table 4).

The intracellular $\mathrm{CO}_{2}$ values were not significantly different among all of the treatments (Table 4). The highest value of intracellular $\mathrm{CO}_{2}$ was noted in the leaves of the 'Topaz' trees; the lowest -in the leaves of the 'Red Boskoop' trees (Table 4).

Table 4. Physiological parameters of maiden apple trees depending on treatment and cultivar.

\begin{tabular}{|c|c|c|c|c|c|c|c|c|c|}
\hline & & Control & $\begin{array}{c}\text { Amino- } \\
\text { Plant }\end{array}$ & $\begin{array}{c}\text { Biamino } \\
\text { Plant }\end{array}$ & Bispeed & Fylloton & $\begin{array}{c}\text { Basf. } \\
6-12-6\end{array}$ & $\begin{array}{c}\text { Basf. } \\
\text { 12-4-6+S }\end{array}$ & $\begin{array}{c}\text { Mean for } \\
\text { Cultivar }\end{array}$ \\
\hline \multirow{4}{*}{$\mathrm{Pn}$} & Gala $S$. & $24.6 \mathrm{e}-\mathrm{j}$ * & $22.4 \mathrm{ab}$ & $22.9 \mathrm{~b}-\mathrm{d}$ & $23.8 \mathrm{c}-\mathrm{g}$ & $25.0 \mathrm{~h}-\mathrm{j}$ & $25.7 \mathrm{j}$ & $24.2 \mathrm{e}-\mathrm{i}$ & $24.1 \mathrm{~b}$ \\
\hline & Ligol & $25.5 \mathrm{j}$ & $25.4 \mathrm{ij}$ & $24.7 \mathrm{f}-\mathrm{j}$ & $22.8 \mathrm{bc}$ & $22.2 \mathrm{ab}$ & $25.6 j$ & $24.1 \mathrm{e}-\mathrm{h}$ & $24.3 \mathrm{~b}$ \\
\hline & $\begin{array}{c}\text { R. } \\
\text { Boskoop }\end{array}$ & $21.5 \mathrm{a}$ & $23.9 c-g$ & $23.9 \mathrm{~d}-\mathrm{h}$ & $23.9 \mathrm{~d}-\mathrm{g}$ & $23.7 \mathrm{c}-\mathrm{f}$ & $24.4 \mathrm{e}-\mathrm{i}$ & $23.6 \mathrm{c}-\mathrm{e}$ & $23.6 \mathrm{a}$ \\
\hline & Topaz & $24.8 \mathrm{f}-\mathrm{j}$ & $24.8 \mathrm{~g}-\mathrm{j}$ & $23.8 \mathrm{c}-\mathrm{f}$ & $24.1 \mathrm{e}-\mathrm{h}$ & $22.3 \mathrm{ab}$ & $25.0 \mathrm{~h}-\mathrm{j}$ & $24.6 \mathrm{e}-\mathrm{j}$ & $24.2 \mathrm{~b}$ \\
\hline \multicolumn{2}{|c|}{ Mean for treatment } & $24.1 \mathrm{c}$ & $24.1 \mathrm{C}$ & $23.8 \mathrm{bc}$ & $23.6 \mathrm{~b}$ & $23.3 \mathrm{a}$ & $25.2 \mathrm{~d}$ & $24.1 \mathrm{c}$ & \\
\hline \multirow{4}{*}{$\mathrm{E}$} & Gala S. & $1.7 \mathrm{~b}$ * & $1.4 \mathrm{a}$ & $1.8 \mathrm{bc}$ & $2.1 \mathrm{f}-\mathrm{h}$ & $2.3 \mathrm{hi}$ & $2.4 \mathrm{i}$ & $2.3 \mathrm{~g}-\mathrm{i}$ & $2.0 \mathrm{a}$ \\
\hline & Ligol & $1.8 \mathrm{bc}$ & $2.1 \mathrm{fg}$ & $2.0 \mathrm{~d}-\mathrm{f}$ & $1.9 \mathrm{~cd}$ & $1.9 \mathrm{c}-\mathrm{e}$ & $2.0 \mathrm{~d}-\mathrm{f}$ & $1.8 \mathrm{bc}$ & $2.0 \mathrm{a}$ \\
\hline & $\begin{array}{c}\text { R. } \\
\text { Boskoop }\end{array}$ & $1.8 \mathrm{bc}$ & $1.8 \mathrm{bc}$ & $1.8 \mathrm{bc}$ & $2.1 \mathrm{e}-\mathrm{g}$ & $2.0 \mathrm{~d}-\mathrm{f}$ & $2.2 \mathrm{f}-\mathrm{h}$ & $2.2 \mathrm{f}-\mathrm{h}$ & $2.0 \mathrm{a}$ \\
\hline & Topaz & $2.9 \mathrm{j}$ & $3.2 \mathrm{k}$ & $3.3 \mathrm{kl}$ & $3.5 \mathrm{~lm}$ & $3.4 \mathrm{~lm}$ & $3.4 \mathrm{~lm}$ & $3.5 \mathrm{~m}$ & $3.3 \mathrm{~b}$ \\
\hline \multicolumn{2}{|c|}{ Mean for treatment } & $2.1 \mathrm{a}$ & $2.2 \mathrm{~b}$ & $2.3 \mathrm{c}$ & $2.4 \mathrm{~d}$ & $2.4 \mathrm{de}$ & $2.6 \mathrm{f}$ & $2.5 \mathrm{ef}$ & \\
\hline \multirow{3}{*}{ C } & Gala S. & $125.9 \mathrm{~b}-\mathrm{f}^{*}$ & $102.5 \mathrm{ab}$ & $123.7 \mathrm{~b}-\mathrm{e}$ & $139.5 c-j$ & $147.1 \mathrm{~d}-\mathrm{j}$ & $133.5 \mathrm{c}-\mathrm{h}$ & $142.5 c-j$ & $130.7 \mathrm{a}$ \\
\hline & Ligol & $144.2 \mathrm{c}-\mathrm{j}$ & $140.3 \mathrm{c}-\mathrm{j}$ & $124.9 \mathrm{~b}-\mathrm{e}$ & $125.7 \mathrm{~b}-\mathrm{e}$ & $131.2 \mathrm{c}-\mathrm{g}$ & $135.2 \mathrm{c}-\mathrm{h}$ & $119.7 \mathrm{a}-\mathrm{c}$ & $131.6 \mathrm{a}$ \\
\hline & $\begin{array}{c}\text { R. } \\
\text { Boskoop }\end{array}$ & $132.5 \mathrm{c}-\mathrm{h}$ & $133.8 \mathrm{c}-\mathrm{h}$ & $132.3 \mathrm{c}-\mathrm{h}$ & $97.5 \mathrm{a}$ & 138.7 c-i & $163.0 \mathrm{j}$ & $122.1 \mathrm{~b}-\mathrm{d}$ & $131.4 \mathrm{a}$ \\
\hline & Topaz & $147.4 \mathrm{e}-\mathrm{j}$ & $154.8 \mathrm{~h}-\mathrm{j}$ & $148.9 \mathrm{f}-\mathrm{j}$ & $132.9 \mathrm{c}-\mathrm{h}$ & $161.1 \mathrm{ij}$ & $150.8 \mathrm{~g}-\mathrm{j}$ & $153.7 \mathrm{~h}-\mathrm{j}$ & $149.9 \mathrm{~b}$ \\
\hline \multicolumn{2}{|c|}{ Mean for treatment } & $137.5 \mathrm{bc}$ & $132.8 \mathrm{~b}$ & $132.4 \mathrm{~b}$ & $123.9 \mathrm{a}$ & $144.5 \mathrm{c}$ & $145.6 \mathrm{C}$ & $134.5 \mathrm{~b}$ & \\
\hline \multirow{3}{*}{$\mathrm{I}$} & Gala S. & $211.0 \mathrm{~b}-\mathrm{d}^{*}$ & $181.7 \mathrm{a}$ & $225.7 \mathrm{~d}-\mathrm{f}$ & $258.1 \mathrm{j}-\mathrm{m}$ & $251.2 \mathrm{~h}-\mathrm{k}$ & $222.7 \mathrm{~d}-\mathrm{f}$ & $250.5 \mathrm{~g}-\mathrm{k}$ & $228.7 \mathrm{~b}$ \\
\hline & Ligol & $228.5 \mathrm{~d}-\mathrm{f}$ & $235.6 \mathrm{e}-\mathrm{h}$ & $224.7 \mathrm{~d}-\mathrm{f}$ & $238.8 \mathrm{f}-\mathrm{i}$ & $258.0 \mathrm{j}-1$ & $230.0 \mathrm{~d}-\mathrm{g}$ & $226.5 \mathrm{~d}-\mathrm{f}$ & $234.6 \mathrm{c}$ \\
\hline & $\begin{array}{c}\text { R. } \\
\text { Boskoop }\end{array}$ & $187.0 \mathrm{a}$ & $196.7 \mathrm{ab}$ & $193.5 \mathrm{ab}$ & $228.2 \mathrm{~d}-\mathrm{f}$ & $217.8 \mathrm{c}-\mathrm{e}$ & $242.9 \mathrm{f}-\mathrm{j}$ & $199.2 \mathrm{a}-\mathrm{c}$ & $209.3 \mathrm{a}$ \\
\hline \multirow{2}{*}{\multicolumn{2}{|c|}{$\begin{array}{c}\text { Topaz } \\
\text { Mean for treatment }\end{array}$}} & $256.4 \mathrm{i}-1$ & $271.71-\mathrm{n}$ & $281.8 n$ & $270.1 \mathrm{k}-\mathrm{n}$ & $277.5 \mathrm{mn}$ & $251.9 \mathrm{~h}-\mathrm{k}$ & $271.51-n$ & $268.7 \mathrm{~d}$ \\
\hline & & $220.7 \mathrm{a}$ & $221.4 \mathrm{a}$ & $231.4 \mathrm{~b}$ & 248.8 c & $251.1 \mathrm{c}$ & $236.9 \mathrm{~b}$ & $236.9 \mathrm{~b}$ & \\
\hline
\end{tabular}

* Data followed by the same letters do not differ significantly at $p=0.05$ for each parameter, according to Tukey's test. Pn-net photosynthesis rate $\left(\mu \mathrm{mol} \mathrm{CO} 2 \cdot \mathrm{m}^{-2} \cdot \mathrm{s}^{-1}\right), \mathrm{E}$-transpiration rate $\left(\mu \mathrm{mol} \mathrm{H} \mathrm{H}_{2} \mathrm{O} \cdot \mathrm{m}^{-2} \cdot \mathrm{s}^{-1}\right), \mathrm{C}$ - stomatal conductance $\left(\mathrm{mol} \mathrm{H}_{2} \mathrm{O} \cdot \mathrm{m}^{-2} \cdot \mathrm{s}^{-1}\right), \mathrm{I}_{-}$intracellular $\mathrm{CO}_{2}$ $\left(\mathrm{mol} \mathrm{CO} 2 \cdot \mathrm{mol}^{-1}\right)$.

There was a significant negative correlation between the net photosynthetic rate (Pn) and transpiration rate (E). On the other hand, there were significant positive correlations between the transpiration rate $(\mathrm{E})$ and stomatal conductance $(\mathrm{C})$, transpiration rate $(\mathrm{E})$ and intracellular $\mathrm{CO}_{2}$ (I), as well as stomatal conductance (C) and intracellular $\mathrm{CO}_{2}$ (I) (Table 5). 
Table 5. The correlations between the studied physiological parameter of maiden apple trees in the year 2017.

\begin{tabular}{ccccc}
\hline Parameters & Pn & E & C & I \\
\hline Pn & 1.00 & & & \\
E & $-0.17^{*}$ & 1.00 & & \\
C & 0.05 & $0.65^{*}$ & 1.00 & 1.00 \\
I & -0.05 & $0.71^{*}$ & $0.67^{*}$ &
\end{tabular}

The level of significance $p=0.05$, Pearson's linear correlation coefficient. For an explanation, see Table 4 . * Significant relationship between parameters.

\section{Discussion}

\subsection{Growth}

The experiment showed that both the biostimulants and fertilisers applied to the leaves of the maiden apple trees improved all growth parameters of the maiden apple trees. According to Grzyb et al. [51], thanks to biostimulants, reduced doses of mineral fertilisers may be sufficient for good growth of maiden apple trees in a nursery. A further study conducted by Grzyb et al. [52] on maiden apple trees showed that biostimulants (seaweed extract) applied to soil resulted in similar values of growth parameters to full mineral fertilisation. Other authors did not always observe the positive effect of different biostimulants on the growth of fruit trees in orchards [53,54] and nurseries [55].

In our experiment, the Aminoplant preparation significantly increased the growth parameters of the maiden apple trees, as compared with the control combination. Grabowska et al. [22] applied this biostimulant in a carrot plantation and observed a similar effect. On the other hand, Kunicki et al. [23] applied this biostimulant to spinach, but it had no significant effect on the growth of the plants. Perhaps the area of uptake of the biostimulator by the leaves of individual plant species influenced different results. Grzyb et al. [52] found BioFeed Amin (plant amino acid extract) to be the most effective in improving the growth of maiden apple trees. According to studies conducted in orchards, the same preparation stimulated the growth of apple trees [56,57].

In our experiment, the foliar treatment of the maiden apple trees with the Biamino Plant preparation significantly improved their growth parameters, as compared with the control combination. Other authors applied preparations based on amino acids and peptides in a strawberry plantation and observed a similar beneficial effect $[58,59]$. On the other hand, Lisiecka et al. [60] conducted a study on the foliar application of Aminoflor (an organic complex of amino acids and peptides) to strawberry mother plants and found that the preparation did not stimulate their growth. However, the results of the impact of biostimulants on the same plant species depend on many factors, including weather conditions, soil quality, the level of basic fertilisation and even the cultivar.

In our experiment, the treatment of the maiden trees with the Bispeed preparation resulted in the highest values of the following parameters: diameter, total length of side shoots and fresh weight. However, these results were not significantly different with respect to some other foliar treatments. Similarly, Klimek et al. [61] applied the Asahi preparation (sodium para-nitrophenolate $0.3 \%$, sodium ortho-nitrophenolate $0.2 \%$ and sodium 5-nitroguaiacolate $0.1 \%$ ) to maiden apple trees and observed its significant effect on their height, number and length of side shoots. Wysocki et al. [62] used this biostimulant in a strawberry plantation but observed no improvement in the yield.

Similar to other biostimulants, the Fylloton preparation had positive effects on the growth parameters of the maiden apple trees in the nursery, especially on the number of side shoots. However, this result was not significantly different with respect to three other biostimulant treatments. Grzyb et al. [52,63] also observed that another preparation based on marine algae improved the growth of maiden apple and cherry trees in a nursery. Basak [30] observed that the foliar application of preparations made from seaweed positively affected the growth and yield of apple trees. Norrie et al. [64] observed a similar effect by using marine plant extracts in a study on grapevines. 
Our experiment showed good results of the foliar application of Basfoliar 6-12-6 and Basfoliar 12-4-6+S fertilisers. Mosa et al. [57] used the Florovit Natura fertiliser in combination with beneficial bacteria in an orchard and observed the highest increase in the apple tree trunk diameter.

Only the 'Red Boskoop' maiden trees did not differ significantly in the number and total length of their side shoots after the treatment with the biostimulants. There was a significant improvement in these growth parameters in the other three cultivars. Basak [29] also found that $\mathrm{Kelpak}^{\circledR}$ (contains natural auxins and cytokinins extracted from Ecklonia maxima) and Goëmar BM $86^{\circledR}$ (contains amino acids, vitamins, phytohormones and oligosaccharides extracted from Ascophyllum nodosum, and the mineral nutrients $\mathrm{N}, \mathrm{Mg}$ and $B^{\prime}$ ) stimulated the elongation of shoots and sometimes induced the better branching of trees. There were different results of the studies conducted by Grzyb et al. [65,66], who observed that only some biostimulant containing extracts from several seaweed species reinforced with humic and fulvic acids induced the growth of side shoots of apple trees to a greater extent than soil fertilisation. In our experiment, the growth parameters of the maiden trees of the four cultivars improved in a preparation-dependent manner. This may have been caused by the fact that each of the cultivars was characterised by different genetic conditions for growth. Other authors [52,66] also observed that the maiden apple trees of two cultivars in a nursery reacted differently to the same fertilisers and biopreparations. Basak [29] also noted that the same biostimulants applied to apple trees of different cultivars resulted in their different ability to develop side shoots.

The plants used in our experiment reacted to the type of fertilisers in a cultivar-specific manner. Apart from that, some authors $[67,68]$ believe that biostimulants better adapt plants to changing cultivation conditions. In addition, our experiment showed that limited mineral fertilisation did not decrease the growth parameters of the maiden apple trees, although there were lower values of some physiological parameters under analysis.

\subsection{Physiological Parameters}

The values of the net photosynthetic rate and the stomatal conductance in the leaves of the maiden apple trees in the control combination were higher or equal to the values of these parameters compared to the other treatments. Our observation is not in line with the opinion of other authors [11,69] who found an increased net photosynthetic rate and reduced transpiration rate and stomatal conductance in plants treated with biostimulants. Conesa et al. [70] proved that the treatment of maiden citrus trees grown in containers with biostimulants increased their photosynthetic capacity by $32 \%$. However, there was an additional stress factor in this experiment in the form of a limited amount of substrate in the container, which could have resulted in better results of using biostimulants. In this experiment, the values of the net photosynthetic rate and stomatal conductance in the trees treated with sea algae extracts were higher than those in the untreated ones. In another experiment [71], in one of the two years of observation, the cherry trees treated with an Ascophyllum nodosum extract exhibited greater net $\mathrm{CO}_{2}$ assimilation than the control plants. Kocira et al. [35] proved that the Fylloton biostimulant positively affected the function of the photosynthetic apparatus of Moldavian dragonheads. Fylloton improved most of the physiological parameters analysed in this experiment. There were similar effects observed in other studies $[19,30]$, in which plants were treated with biostimulants based on seaweed extracts or seaweed extracts with amino acids [72]. The differences in the effect of the Fyloton preparation in our experiment in relation to the results of other authors may result from the fact that in the analysed experiment, half the dose of mineral fertilisation was used. The treatment of the plants with Basfoliar 6-12-6 resulted in higher values of most of the physiological parameters tested in our experiment compared to the rest of the treatments. Mosa et al. [57] observed that the treatment of plants with the Florovit Natura fertiliser (93 N\%, $1.3 \mathrm{P}_{2} \mathrm{O}_{5} \%, 3 \mathrm{~K}_{2} \mathrm{O} \%, 0.008 \mathrm{~B} \%, 0.004 \mathrm{Cu} \%, 0.018 \mathrm{Fe} \%, 0.006 \mathrm{Mn} \%, 0.006 \mathrm{Zn} \%$ and humic substances) improved their photosynthesis index. A high photosynthetic rate was found to increase the yield of crops [73]. According to Proietti et al. [74], in general, the 
values of the leaf transpiration rate (E), stomatal conductance (C), and intracellular $\mathrm{CO}_{2}$ (I $\mathrm{CO}_{2}$ ) are associated with that of the net photosynthetic rate (Pn). However, the values of the correlation coefficients in our experiment did not confirm the relations between these parameters. According to some authors [75-77], trees grow larger as a result of increased photosynthesis. This happens because they develop a larger leaf area and capture more light. In consequence, their source activity increases and they grow larger. Our experiment did not fully confirm the dependence between the higher intensity of photosynthesis and stomatal conductance and the better growth of maiden apple trees. The lowest values of the leaf transpiration coefficient and internal carbon dioxide concentration were noted only in the control combination, which resulted in the poorest growth of the maiden apple trees. According to Zhao et al. [78] and Bown et al. [79], if there is a reduced supply of nitrogen for plants, and almost always if there is a lower supply of phosphorus and potassium, the chlorophyll concentration decreases and so does the rate of photosynthesis. In our experiment, this effect was observed for the parameters of some physiological processes occurring in the maiden apple trees cultivated with reduced mineral fertilisation. However, this reduction in fertilisation should be monitored on an ongoing basis through soil and plant material analyses because the initial content of nutrients in the soil may be depleted.

\section{Conclusions}

The results of the experiment led to the conclusions that the foliar spraying of maiden apple trees with selected biostimulants and fertilisers, while mineral fertilisation was reduced by half, usually significantly improved the plants' growth parameters in comparison with mineral fertilisation at a full dose. The biostimulants and fertilisers applied in the experiment had diversified effects on the growth of the maiden apple trees of individual cultivars. For the future, it is worth examining the effect of foliar biostimulants under more stressful conditions, such as no soil fertilisation and no irrigation in periods of drought. An analysis of the costs of using this type of plant care treatment should also be performed.

Author Contributions: S.Ś. and A.A. authors contributed to the study conception and design. Material preparation, data collection and analysis were performed by S.Ś., A.A. and J.B. The first draft of the manuscript was written by S.S. and all authors commented on the previous version of the manuscript. All authors have read and agreed to the published version of the manuscript.

Funding: Publication was co-financed within the framework of the Polish Ministry of Science and Higher Education's program: 'Regional Initiative Excellence' in the year 2019-2022 (No. 005/RID/2018/19)', financing amount 1,200,000 PLN.

Institutional Review Board Statement: Not applicable.

Informed Consent Statement: Not applicable.

Data Availability Statement: Data sharing not applicable.

Acknowledgments: Not applicable.

Conflicts of Interest: The authors declare that there are no conflicts of interest related to this article.

\section{References}

1. Dong, S.; Neilsen, D.; Neilsen, G.H.; Fuchigami, L.H. Foliar N application reduces soil NO3--N leaching loss in apple orchards. Plant Soil 2005, 268, 357-366. [CrossRef]

2. Khan, W.; Rayirath, U.P.; Subramanian, S.; Jithesh, M.N.; Rayorath, P.; Hodges, D.M.; Critchley, A.T.; Craigie, J.S.; Norrie, J.; Prithiviraj, B. Seaweed Extracts as Biostimulants of Plant Growth and Development. J. Plant Growth Regul. 2009, $28,386-399$. [CrossRef]

3. Abdelaziz, M.; Pokluda, R.; Abdelwahab, M. Influence of compost, microorganisms and NPK fertilizer upon growth, chem-ical composition and essential oil production of Rosmarinus officinalis L. Not. Bot. Hort. Agrobot. 2007, 35, 86-90. [CrossRef]

4. Totten, F.W.; Liu, H.; Mccarty, L.B.; Baldwin, C.M.; Bielenberg, D.G.; Toler, J.E. Efficiency of Foliar Versus Granular Fertilization: A Field Study of Creeping Bentgrass Performance. J. Plant Nutr. 2008, 31, 972-982. [CrossRef]

5. Fernández, V.; Eichert, T. Uptake of Hydrophilic Solutes through Plant Leaves: Current State of Knowledge and Perspectives of Foliar Fertilization. Crit. Rev. Plant Sci. 2009, 28, 36-68. [CrossRef] 
6. Wójcik, P. Uptake of mineral nutrients from foliar fertilization. J. Fruit Ornam. Plant Res. 2004, 12, 201-218.

7. Pfeiffer, B.; Eis, B.; Zimmer, J.; Fieger-Metag, N. Optimizing crop loading of apples and pears-Results (foliar fertilizers, thinning). In Proceedings of the Ecofruit. 13th International Conference on Cultivation Technique and Phytopathological Problems in Organic Fruit-Growing, Weinsberg, Germany, 18-20 February 2008; pp. 324-329.

8. Amiri, M.E.; Fallahi, E.; Golchin, A. Influence of Foliar and Ground Fertilization on Yield, Fruit Quality, and Soil, Leaf, and Fruit Mineral Nutrients in Apple. J. Plant Nutr. 2008, 31, 515-525. [CrossRef]

9. Li, M.; Liu, Z. Effect of reducing application amount of base fertilizer and increasing application time of leaf fertilizer on corn yield. Agric. Sci. Technol. 2015, 16, 947-950.

10. Bi, G.; Scagel, C. Nitrogen foliar feeding has advantages. Nurs. Manage. Prod. 2007, 23, 43-46.

11. Ertani, A.; Schiavon, M.; Altissimo, A.; Franceschi, C.; Nardi, S. Phenol-containing organic substances stimulate phenylpropanoid metabolism in Zea mays. J. Plant Nutr. Soil Sci. 2011, 174, 496-503. [CrossRef]

12. Ghannam, A.; Abbas, A.; Alek, H.; Al-Waari, Z.; Al-Ktaifani, M. Enhancement of local plant immunity against tobacco mosaic virus infection after treatment with sulphated-carrageenan from red alga (Hypnea musciformis). Physiol. Mol. Plant Pathol. 2013, 84, 19-27. [CrossRef]

13. Vijayanand, N.; Ramya, S.S.; Rathinavel, S. Potential of liquid extracts of Sargassum wightii on growth, biochemical and yield parameters of cluster bean plant. Asian Pac. J. Reprod. 2014, 3, 150-155. [CrossRef]

14. Povero, G.; Mejia, J.F.; Di Tommaso, D.; Piaggesi, A.; Warrior, P. A Systematic Approach to Discover and Characterize Natural Plant Biostimulants. Front. Plant Sci. 2016, 7, 435. [CrossRef] [PubMed]

15. Yakhin, O.I.; Lubyanov, A.; Yakhin, I.; Brown, P.H. Biostimulants in Plant Science: A Global Perspective. Front. Plant Sci. 2017, 7, 2049. [CrossRef] [PubMed]

16. Du Jardin, P. Plant biostimulants: Definition, concept, main categories and regulation. Sci. Hortic. 2015, 196, 3-14. [CrossRef]

17. Wally, O.S.D.; Critchley, A.T.; Hiltz, D.; Craigie, J.S.; Han, X.; Zaharia, L.I.; Abrams, S.R.; Prithiviraj, B. Regulation of Phytohormone Biosynthesis and Accumulation in Arabidopsis Following Treatment with Commercial Extract from the Marine Macroalga Ascophyllum nodosum. J. Plant Growth Regul. 2013, 32, 324-339. [CrossRef]

18. De Pascale, S.; Rouphael, Y.; Colla, G. Plant biostimulants: Innovative tool for enhancing plant nutrition in organic farming. Eur. J. Hortic. Sci. 2018, 82, 277-285. [CrossRef]

19. Jannin, L.; Arkoun, M.; Etienne, P.; Laîné, P.; Goux, D.; Garnica, M.; Fuentes, M.; Francisco, S.S.; Baigorri, R.; Cruz, F.; et al. Brassica napus Growth is Promoted by Ascophyllum nodosum (L.) Le Jol. Seaweed Extract: Microarray Analysis and Physiological Characterization of N, C, and S Metabolisms. J. Plant Growth Regul. 2013, 32, 31-52. [CrossRef]

20. Matsubayashi, Y.; Sakagami, Y. Peptide hormones in plants. Annu. Rev. Plant Biol. 2006, 57, 649-674. [CrossRef]

21. Maini, P. The experience of the first biostimulant, based on amino acids and peptides: A short retrospective review on the laboratory researches and the practical results. Fertil. Agrorum 2006, 1, $29-43$.

22. Grabowska, A.; Kunicki, E.; Sękara, A.; Kalisz, A.; Wojciechowska, R. The effect of cultivar and biostimulant treatment on the carrot yield and its quality. Veg. Crops Res. Bull. 2012, 77, 37-48. [CrossRef]

23. Kunicki, E.; Grabowska, A.; Sękara, A.; Wojciechowska, R. The effect of cultivar type, time of cultivation, and biostimulant treatment on the yield of spinach (Spinacia oleracea L.). Folia Hortic. 2010, 22, 9-13. [CrossRef]

24. Gajc-Wolska, J.; Kowalczyk, K.; Nowecka, M.; Mazur, K.; Metera, A. Effect of organic-mineral fertilizers on the yield and quality of endive (Cichorium endivia L.). Acta Sci. Pol. Hortorum Cultus 2012, 11, 189-200.

25. Mladenova, Y.I.; Maini, P.; Mallegni, C.; Goltsev, V.; Vladova, R.; Vinarova, K.; Rotcheva, S. Siapton-An amino-acid-based biostimulant reducing osmostress metabolic changes in maize. Agro. Food Ind. Hi-Tech. 1998, 9, 18-22.

26. Djanaguiraman, M.; Sheeba, J.A.; Devi, D.D.; Bangarusamy, U. Effect of Atonik Seed Treatment on Seedling Physiology of Cotton and Tomato. J. Biol. Sci. 2005, 5, 163-169. [CrossRef]

27. Djanaguiraman, M.; Sheeba, J.A.; Devi, D.D.; Bangarusamy, U. Response of Cotton to Atonik and TIBA for Growth, Enzymes and Yield. J. Biol. Sci. 2005, 5, 158-162. [CrossRef]

28. Colla, G.; Nardi, S.; Cardarelli, M.; Ertani, A.; Lucini, L.; Canaguier, R.; Rouphael, Y. Protein hydrolysates as biostimulants in horticulture. Sci. Hortic. 2015, 196, 28-38. [CrossRef]

29. Basak, A. Effect of Preharvest Treatment with Seaweed Products, Kelpak®and Goëmar BM $86^{\circledR}$, on Fruit Quality in Apple. Int. J. Fruit Sci. 2008, 8, 1-14. [CrossRef]

30. Spinelli, F.; Fiori, G.; Noferini, M.; Sprocatti, M.; Costa, G. Perspectives on the use of a seaweed extract to moderate the negative effects of alternate bearing in apple trees. J. Hortic. Sci. Biotechnol. 2009, 84, 131-137. [CrossRef]

31. Mancuso, S.; Azzarello, E.; Mugnai, S.; Briand, X. Marine bioactive substances (IPA extract) improve foliar ion uptake and water stress tolerance in potted Vitis vinifera plants. Adv. Hortic. Sci. 2006, 20, 156-161.

32. Colavita, G.; Spera, N.; Blackhall, V.; Sepulveda, G. EFFECT OF SEAWEED EXTRACT ON PEAR FRUIT QUALITY AND YIELD. Acta Hortic. 2011, 909, 601-607. [CrossRef]

33. Alam, M.Z.; Braun, G.; Norrie, J.; Hodges, D.M. Effect of Ascophyllum extract application on plant growth, fruit yield and soil microbial communities of strawberry. Can. J. Plant Sci. 2013, 93, 23-36. [CrossRef]

34. Zhang, X.; Wang, K.; Ervin, E.H. Optimizing Dosages of Seaweed Extract-Based Cytokinins and Zeatin Riboside for Improving Creeping Bentgrass Heat Tolerance. Crop. Sci. 2010, 50, 316-320. [CrossRef] 
35. Kocira, S.; Sujak, A.; Kocira, A.; Wójtowicz, A.; Oniszczuk, A. Effect of Fylloton Application on Photosynthetic Activity of Moldavian Dragonhead (Dracocephalum moldavica L.). Agric. Agric. Sci. Procedia 2015, 7, 108-112. [CrossRef]

36. Sivasankari, S.; Venkatesalu, V.; Anantharaj, M.; Chandrasekaran, M. Effect of seaweed extracts on the growth and biochemical constituents of Vigna sinensis. Bioresour. Technol. 2006, 97, 1745-1751. [CrossRef] [PubMed]

37. Fan, X.; Gordon-Weeks, R.; Shen, Q.; Miller, A.J. Glutamine transport and feedback regulation of nitrate reductase activity in barley roots leads to changes in cytosolic nitrate pools. J. Exp. Bot. 2006, 57, 1333-1340. [CrossRef] [PubMed]

38. Anjum, S.A.; Wang, L.; Farooq, M.; Xue, L.; Ali, S. Fulvic Acid Application Improves the Maize Performance under Well-watered and Drought Conditions. J. Agron. Crop. Sci. 2011, 197, 409-417. [CrossRef]

39. Ferrini, F.; Nicese, F. Response of English Oak (Quercus robur L.) Trees to biostimulants application in the urban environ-ment. J. Arboric. 2002, 28, 70-75.

40. Botta, A. Enhancing plant tolerance to temperature stress with amino acids: An approach to their mode of action. Acta Hortic. 2013, 1009, 29-35. [CrossRef]

41. Cristiano, G.; Pallozzi, E.; Conversa, G.; Tufarelli, V.; De Lucia, B. Effects of an Animal-Derived Biostimulant on the Growth and Physiological Parameters of Potted Snapdragon (Antirrhinum majus L.). Front. Plant Sci. 2018, 9, 861. [CrossRef]

42. Molassiotis, A.; Job, D.; Ziogas, V.; Tanou, G. Citrus Plants: A Model System for Unlocking the Secrets of NO and ROS-Inspired Priming Against Salinity and Drought. Front. Plant Sci. 2016, 7, 229. [CrossRef]

43. Rios, J.J.; Carrasco-Gil, S.; Abadía, A.; Abadía, J. Using Perls Staining to Trace the Iron Uptake Pathway in Leaves of a Prunus Rootstock Treated with Iron Foliar Fertilizers. Front. Plant Sci. 2016, 7, 893. [CrossRef]

44. Wójcik, P.; Gubbuk, H.; Akgül, H.; Gunes, E.; Ucgun, K.; Koçal, H.; Küçükyumuk, C. Response of 'granny smith' apple trees to foliar titanium sprays under conditions of low soil availability of iron, manganese, and zinc. J. Plant Nutr. 2010, 33, 1914-1925. [CrossRef]

45. Świerczyński, S.; Stachowiak, A. The influence of three fertilizers and preparation Gibrescol used as the foliage spraying on the growth and nutritional status of maiden apple trees in a nursery. Ann. Univ. Mariae Curie-Skłodowska. Sect. E Agric. 2009, 64, 78-85.

46. Świerczyński, S.; Stachowiak, A.; Golcz, M. Effect of promalin and foliar fertilizers on the growth of maiden trees of two apple cultivars in a nursery. Rocz. Ar. Pozn. 2005, 39, 97-102.

47. Mondragón-Valero, A.; Malheiro, R.; Salazar Hernández, D.M.; Pereira, J.A.; López-Cortés, I. Changes produced by the application of biostimulants on almond rootstocks properties during the nursery process. Adv. Agric. Bot. 2019, 11, 56-71.

48. Saa, S.; Rio, A.O.-D.; Castro, S.; Brown, P.H. Foliar application of microbial and plant based biostimulants increases growth and potassium uptake in almond (Prunus dulcis [Mill.] D. A. Webb). Front. Plant Sci. 2015, 6, 87. [CrossRef]

49. Paunović, S.M.; Miletić, R.; Janković, D.; Janković, S.; Mitrović, M. Effect of Humisol on survival and growth of nursery grafted walnut (Juglans regia L.) plants. Hortic. Sci. 2013, 40, 111-118. [CrossRef]

50. Popenoe, J.; Wilber, L.; Chen, J.J. Biostimulants have minimal effect on the growth of some woody nursery plants. In Proceedings of the Florida State Horticultural Society, Tampa, FL, USA, 4-6 June 2017; Volume 130, pp. 240-244.

51. Grzyb, Z.S.; Piotrowski, W.; Bielicki, P.; Paszt, L.S.; Malusà, E. Effect of different fertilizers and amendments on the growth of apple and sour cherry rootstocks in an organic nursery. J. Fruit Ornam. Plant Res. 2012, 20, 43-53. [CrossRef]

52. Grzyb, Z.S.; Piotrowski, W.; Sas Paszt, L. Treatments comparison of mineral and bio fertilizers in the apple and sour cherry organic nursery. J. Life Sci. 2014, 8, 889-898. [CrossRef]

53. Thalheimer, M.; Paoli, N. Effectiveness of various leaf-applied biostimulants on productivity and fruit quality of apple. Acta Hortic. 2002, 594, 335-339. [CrossRef]

54. Masny, A.; Basak, A.; Żurawicz, E. Effect of foliar application of Kelpak and Goemar BM 86 preparations on yield and fruit quality in two strawberry cultivars. J. Fruit Ornam. Plant Res. 2004, 12, $23-27$.

55. Świerczyński, S.; Borowiak, K.; Bosiacki, M.; Urbaniak, M.; Malinowska, A. Estimation of the growth of 'vanda' maiden sweet cherry trees on three rootstocks and after aplication of foliar fertilization in a nursery. Acta Sci. Pol. Hortorum Cultus 2019, 18, 109-118. [CrossRef]

56. Rozpara, E.; Paśḱ, M.; Bielicki, P.; Sas Paszt, L. Influence of various bio-fertilizers on the growth and fruiting of 'Ariwa' apple trees growing in an organic orchard. J. Res. Appl. Agric. Eng. 2014, 59, 65-68.

57. Mosa, W.-G.; Paszt, L.; Frąc, M.; Przybył, M.; Treder, W.; Klamkowski, K.; Trzciński, P. The influence of biofertilization on the growth, yield and fruit quality of cv. Topaz apple trees. Hortic. Sci. 2016, 43, 105-111. [CrossRef]

58. Żurawicz, E.; Masny, A.; Basak, A. Productivity stimulation in strawberry by application of plant bioregulators. Acta Hortic. 2004, 653, 155-160. [CrossRef]

59. Botta, A.; Marin, C.; Piñol, R.; Ruz, L.; Badosa, E.; Montesinos, E. Study of the mode of action of inicium ${ }^{\circledR}$, A product developed specifically to overcome transplant stress in strawberry plants. Acta Hortic. 2009, 842, 721-724. [CrossRef]

60. Lisiecka, J.; Knaflewski, M.; Spiżewski, T.; Frąszczak, B.; Kałużewicz, A.; Krzesiński, W. The effect of animal protein hy-drolysate on quantity and quality of strawberry daughter plants cv. 'Elsanta'. Acta Sci. Pol. Hortorum Cultus 2011, 10, 31-40.

61. Klimek, K.; Kapłan, M.; Najda, A. Effect of growth regulators on quality of apple tree maidens. Acta Agrophysica 2018, 25, 277-288. [CrossRef]

62. Wysocki, K.; Banaszkiewicz, T.; Kopytowski, J. The effect of Asahi SL and Polyversum WP preparations on the chemical composition of strawberry fruits. Pol. J. Nat. Sci. 2017, 32, 439-450. 
63. Grzyb, Z.S.; Piotrowski, W.; Bielicki, P.; Paszt, L.S. Quality of Apple Maidens as Influenced by the Frequency of Application of Different Fertilizers in the Organic Nursery-Preliminary Results. J. Fruit Ornam. Plant Res. 2012, 20, 41-49. [CrossRef]

64. Norrie, J.; Branson, T.; Keathley, P. Marine plant extracts impact on grape yield and quality. Acta Hortic. 2002, 594, 315-319. [CrossRef]

65. Grzyb, Z.S.; Piotrowski, W.; Sas Paszt, L.; Bielicki, P. The quality of sour cherry maidens fertilized with various bioprepara-tions in an organic nursery. J. Life Sci. 2013, 7, 400-409.

66. Grzyb, Z.S.; Piotrowski, W.; Sas Paszt, L. The residual effects of various bioproducts and soil conditioners applied in the organic nursery on apple tree performance in the period of two years after transplanting. J. Res. Appl. Agric. Eng. 2015, 60, 109-113.

67. Schiavon, M.; Pizzeghello, D.; Muscolo, A.; Vaccaro, S.; Francioso, O.; Nardi, S. High Molecular Size Humic Substances Enhance Phenylpropanoid Metabolism in Maize (Zea mays L.). J. Chem. Ecol. 2010, 36, 662-669. [CrossRef]

68. Berbara, R.L.L.; García, A.C. Humic substances and plant defense metabolism. In Physiological Mechanisms and Adaptation Strategies in Plants under Changing Environment; Ahmad, P., Wani, M.R., Eds.; Springer: New York, NY, USA, 2014; Volume 1, pp. $297-319$.

69. Khan, I.A.; Khatri, A.; Nizamani, G.S.; Siddiqui, M.A.; Raza, S.; Dahar, N. Effect of NPK fertilizers on the growth of sugarcane clone AEC86-347 developed at NIA, Tando Jam, Pakistan. Pak. J. Bot. 2005, 37, 355360.

70. Conesa, M.; Espinosa, P.; Pallarés, D.; Pérez-Pastor, A. Influence of Plant Biostimulant as Technique to Harden Citrus Nursery Plants before Transplanting to the Field. Sustainability 2020, 12, 6190. [CrossRef]

71. Correia, S.; Queirós, F.; Ferreira, H.; Morais, M.C.; Afonso, S.; Silva, A.P.; Gonçalves, B. Foliar Application of Calcium and Growth Regulators Modulate Sweet Cherry (Prunus avium L.) Tree Performance. Plants 2020, 9, 410. [CrossRef]

72. Shehata, S.M.; Abdel-Azem, H.S.; Abou El-Yazeed, A.; El-Gizawy, A.N. Effect of foliar spraying with amino acids and sea-weed extract on growth chemical constitutes, yield and its quality of celeriac plant. Eur. J. Sci. Res. 2011, 58, $257-265$.

73. Nardi, S.; Pizzeghello, D.; Muscolo, A.; Vianello, A. Physiological effects of humic substances on higher plants. Soil Biol. Biochem. 2002, 34, 1527-1536. [CrossRef]

74. Proietti, P.; Nasini, L.; Famiani, F. Effect of different leaf-to-fruit ratios on photosynthesis and fruit growth in olive (Olea europaea L.). Photosynthetica 2006, 44, 275-285. [CrossRef]

75. Famiani, F.; Proietti, P.; Palliotti, A.; Ferranti, F.; Antognozzi, E. Effects of leaf to fruit ratios on fruit growth in chestnut. Sci. Hortic. 2000, 85, 145-152. [CrossRef]

76. Rosati, A.; Paoletti, A.; Al Hariri, R.; Morelli, A.; Famiani, F. Resource investments in reproductive growth proportionately limit investments in whole-tree vegetative growth in young olive trees with varying crop loads. Tree Physiol. 2018, 38, 1267-1277. [CrossRef] [PubMed]

77. Almadi, L.; Paoletti, A.; Cinosi, N.; Daher, E.; Rosati, A.; Di Vaio, C.; Famiani, F. A Biostimulant Based on Protein Hydrolysates Promotes the Growth of Young Olive Trees. Agriculture 2020, 10, 618. [CrossRef]

78. Zhao, D.; Oosterhuis, D.M.; Bednarz, C.W. Influence of Potassium Deficiency on Photosynthesis, Chlorophyll Content, and Chloroplast Ultrastructure of Cotton Plants. Photosynthetica 2001, 39, 103-109. [CrossRef]

79. Bown, H.E.; Watt, M.S.; Mason, E.G.; Clinton, P.W.; Whitehead, D. The influence of nitrogen and phosphorus supply and genotype on mesophyll conductance limitations to photosynthesis in Pinus radiata. Tree Physiol. 2009, 29, 1143-1151. [CrossRef] 